\title{
Riparian Habitat Dissimilarities in Restored and Reference Streams are Associated with Differences in Turtle Communities in the Southeastern Piedmont
}

\author{
Maura Patricia Dudley • Mengchi Ho \\ Curtis J. Richardson
}

Received: 31 January 2014 / Accepted: 13 November 2014 / Published online: 30 November 2014

(C) Society of Wetland Scientists 2014

\begin{abstract}
Few studies have assessed whether restored streams and riparian floodplains support reference communities of certain groups of freshwater organisms, such as turtles. This exploratory study compared turtle assemblages in six reference and six restored streams in the North Carolina Piedmont, which were assessed using standard trapping practices with baited hoop nets. We also quantified turtle-relevant habitat characteristics (structure, water quality, vegetation) through reach-scale surveys to assess potential differences in turtle composition. Turtle abundance at restored sites was more than twice that of references sites and trends existed in the distribution of turtle species, but neither abundance nor composition was found to be statistically different. Habitat characteristics that affect turtle communities were not equivalent between sites, with reference streams having higher canopy cover, and lower total phosphorus, dissolved oxygen and total suspended solids than restored streams. Mantel's test and non-metric multidimensional scaling plots indicated that turtle composition was significantly correlated with habitat and vegetation, and that turtle communities were generally
\end{abstract}

Electronic supplementary material The online version of this article (doi:10.1007/s13157-014-0603-5) contains supplementary material, which is available to authorized users.

M. P. Dudley $\cdot$ M. Ho $\cdot$ C. J. Richardson

Nicholas School of the Environment, Duke University Wetland

Center, Box 90333, Durham, NC 27708, USA

M. Ho

e-mail:mho@duke.edu

C. J. Richardson

e-mail: curtr@duke.edu

Present Address:

M. P. Dudley $(\square)$

Odum School of Ecology, The University of Georgia, 140 E. Green

Street, Athens, GA 30602-2202, USA

e-mail: mdudley3@uga.edu separated between restored and reference streams. These findings suggest a pattern that restored streams with riparian wetlands may provide more suitable habitat than reference streams for most southeastern Piedmont turtle species, but further studies are required to fully examine these patterns.

Keywords Restoration $\cdot$ Turtle $\cdot$ Stream $\cdot$ Riparian · Ecosystem

\section{Introduction}

Despite having ecosystem-based objectives, the impact of restoration on many components of stream ecosystems remains unknown due to a severe lack of biological monitoring (Jähnig et al. 2011). Many stream restoration projects fail to monitor even the most abundant and important organismal groups to determine if their goals have been met (Richardson 2004). Such failure to monitor essential ecological parameters is based on the potentially erroneous assumption that establishing certain structural components and plant species at a stream restoration site will necessarily facilitate the reestablishment of other organisms in the ecosystem (e.g. "Field of Dreams" hypothesis, Hobbs and Cramer 2008; Sudduth et al. 2011). Other barriers, such as lack of funding, time and personnel, prevent comprehensive evaluations of the success of many restorations (Bash and Ryan 2002; Convertino et al. 2013). Furthermore, the US Army Corps of Engineers' (USACE) regulatory guidance for compensatory mitigation through stream restoration does not offer specific, quantitative monitoring parameters that would rigorously evaluate ecosystem function for restoration-based mitigation projects (USACE 2008). Important questions remain as to whether most restored streams contain all of the biotic components necessary for the restoration of full ecological function and diversity, particularly with respect to higher order 
organisms. Consequently, more studies are required to assess the appropriateness of the stream restoration "Field of Dreams" hypothesis to key aquatic and riparian organisms, including aquatic mammals (Brown et al. 2008), birds (Seavy 2012), non-game fish (Raborn and Schramm 2003), amphibians and reptiles.

Aquatic and semi-aquatic freshwater turtles are diverse, abundant (Iverson 1982) and essential organisms in freshwater ecosystems, particularly in the southeast U.S., but are seldom studied in restored stream and wetland sites (Palmer and Braswell 1995; Meyers and Pike 2006; Graham et al. 2010). Freshwater turtles are an important part of the food webs in which they live; turtle eggs and hatchlings provide a food source for organisms from varying trophic levels, while turtles themselves vary widely in their dietary requirements (Bodie 2001; Aresco 2009). The roles of turtles in freshwater ecosystems are thought to include exchanging energy among aquatic, riparian and terrestrial ecosystems, altering nutrient cycling, and dispersing seeds for terrestrial plants (Cheung and Dudgeon 2006; Pearse et al. 2006; Conover and Klein 2010). Turtle assemblages may also serve as indicators of biotic and abiotic characteristics of freshwater habitats, including hydrology, turbidity and primary and secondary production (Bodie et al. 2000). Thus, studying how turtle communities differ in restored streams can provide valuable information about how successfully restoration replicates predegradation conditions.

Despite their importance to the ecological functioning of stream and riparian ecosystems, turtle communities are rarely quantified in restored stream or wetland sites, and there are no studies to our knowledge that look at how stream and riparian restoration through geomorphic alterations affect turtle assemblages. Yet stream restoration has the potential to significantly affect the composition of turtle assemblages. For example, restoration may improve turtle habitat by reducing the amount of canopy cover as a result of tree removal, altering the number of basking sites, and increasing wetland vegetation through better connection with the floodplain (Barrett and Guyer 2008). Alternatively, numerous studies have documented no improvement in other taxonomic groups (such as macroinvertebrates) in restored streams (Palmer et al. 2009; Ernst et al. 2012); this may indicate a failure to fully restore the ecology of a degraded stream and its adjacent riparian habitat, which may have negative consequences for turtles. Additionally, the process of restoration using geomorphic methodologies can be disruptive to higher order organisms (Heinrich et al. 2014), and native turtles may be displaced or killed during the process of restoration.

The North Carolina Piedmont offers an ideal setting for studying the effects of stream and riparian restoration on turtle communities. Forested and agricultural lands in the southeastern Piedmont are being rapidly cleared for development, as population growth burgeons (Napton et al. 2010), and degradation of stream water quality and ecosystem health is prevalent in urbanizing areas of the Piedmont of Georgia (Schnoonover and Lockaby 2006), South Carolina (Lewis et al. 2007), North Carolina (NC; Gage et al. 2004; Richardson et al. 2011), and Virginia and Maryland (Horwitz et al. 2008; Groffman et al. 2003). In response to rapid habitat degradation, restoration efforts have accelerated in the Piedmont of NC. Consequently this region offers a high number of restored reaches from which to select study sites, and streams within this area support turtle communities representative of the other states within the southeastern Piedmont, thus providing excellent locations for studying systems representative of the greater physiographic region (Conant and Collins 1998).

The southeastern Piedmont is home to a large variety of aquatic and semi-aquatic turtle species (Palmer and Braswell 1995). Within the central part of the Piedmont, there are ten species of turtle that can be found in stream ecosystems. Clemmys guttata (spotted turtle) prefers grassy wetlands and blackwater streams (Buhlmann et al. 2008; LeGrand et al. 2008), and it is a species of concern in Georgia, South Carolina, and North Carolina. Chrysemys picta (painted turtle) and Chelydra serpentina (common snapping turtle) are dietary generalists and live in a variety of freshwater habitats in the Piedmont (Buhlmann et al. 2008). Found in all southeastern Piedmont states, Kinosternon subrubrum (eastern mud turtle) prefers shallow aquatic habitats with suitable terrestrial habitats nearby for aestivation and hibernation (Semlitsch and Bodie 2003; Wilson et al. 2014b); Kinosternon baurii (striped mud turtle) can be found in streams, but are much less common in moving water (Wilson et al. 2014b). Pseudemys floridana (Florida cooter) and Pseudemys concinna (river cooter) are more common in larger water bodies, but can be found in smaller blackwater streams (Buhlmann et al. 2008). Sternotherus odoratus (common musk turtle) is highly aquatic, moving overland only if forced to do so by displacement or drought. Two distinguishable sub-species of Trachemys scripta have been identified in the Piedmont. T. scripta scripta (yellow-bellied slider) is a habitat generalist and commonly found in North Carolina, South Carolina and Georgia (Wilson et al. 2014a). The native range of T. scripta elegans (red-eared slider) is in the Mississippi River Basin of the US, and it has been introduced in a number of watersheds outside of this range within Maryland, Virginia, North Carolina, and South Carolina (Somma et al. 2014).

Our study aims to determine if recently restored stream and riparian ecosystems support turtle species assemblages equivalent to those in natural reference streams in the same physiographic region. We measured turtle assemblage characteristics and important stream and riparian habitat features in six reference and six restored streams. We addressed the following questions in this exploratory study: (1) do reference and restored sites differ by turtle abundance and/or turtle species 
composition?; (2) do ecologically important habitat characteristics differ between restored and reference streams?; and (3) do habitat characteristics correspond with turtle community composition?

\section{Methods}

\section{Site Selection}

Our study compared turtle species assemblages among six restored and six natural reference streams in the $\mathrm{NC}$ Piedmont (Fig. 1, Table 1). Three criteria for selection of restored sites were: (1) located within the NC Piedmont region; (2) included a stream channel restoration component; and (3) were between their second and fifth growing seasons since the completion of restoration. In addition, all six streams were restored using geomorphic-based restoration methodologies (primarily Natural Channel Design; Doll et al. 2003), with riparian vegetation planted at the completion of construction. Comparable reference streams were considered if they were within $12 \mathrm{~km}$ of at least one restored stream location and if their biological integrity was not known to be compromised, according to the North Carolina 303d list of impaired water bodies (NCDWQ 2008). Additional characteristics considered in reference stream site selection included similar size and stream order, predominantly forested land cover and riparian areas, and permission from property owners to access the streams.

\section{Aquatic Turtle Sampling}

Aquatic turtle sampling occurred via hoop-net turtle traps ( $0.76 \mathrm{~m}$ diameter hoop, $1.83 \mathrm{~m}$ long and $3.8 \mathrm{~cm}$ mesh net) (Memphis Net and Twine, Model TN215). Three traps were set within a 60-m reach according to standard methods (Steen and Gibbs 2004) and checked daily. Although species and sex biases have been documented with this trapping method (DonnerWright et al. 1999; Bodie and Semlitsch 2000; Tran et al. 2007), the use of aquatic hoop traps for freshwater community studies is common, widely accepted and effective in studies of semi-aquatic turtle communities (Conner et al. 2005; Gibbs and Steen 2005; Glorioso et al. 2010).

Trapping occurred during the summer of 2009 at three separate intervals: late May to early June, mid-June to early July, and mid- to late-July. Every stream was visited for the same number of nights during each interval, totaling 12 trap nights spent at each site. Because it was not possible to trap at all 12 locations simultaneously, sites were visited in groups of four (two restored and two reference streams) based on relative locations within the study area.

After removing any captured turtles for further measurements, the empty trap was returned to its original location. For each turtle captured, the species, sex, and location were recorded, and standard length (plastron) and mass measurements were made. Captured turtles were individually identified by making unique notching in the shell (Ernst 1971) or using photographs of natural scarring (for more aggressive species), and released on site.

\section{Habitat Characterization}

The stream reach was characterized by measuring habitat characteristics (structure and water quality) and riparian vegetation. Stream structure was defined by pool width, pool depth, bank slope, and canopy cover. Pool width was calculated as the mean baseflow maximum wetted width for each pool where a turtle trap was located. Pool depth was determined by taking the mean of five depth measurements within each pool. Mean bank slope (water surface to floodplain) was determined by taking three slope readings using a magnetic slope instrument at the beginning, middle, and end of the studied reach. Percent canopy cover served as a proxy for the amount of sunlight reaching the stream. A wide-angle photo was captured with a digital camera at chest height $(\sim 1.2 \mathrm{~m})$ from the middle of the stream, and percent cover was calculated by determining the proportion of dark pixels in each photo using the ImageJ software program (Abramoff et al. 2004).

Water quality measurements were conducted at least $48 \mathrm{~h}$ after a rain event to minimize the occurrence of anomalies as a result of runoff. Dissolved oxygen concentration and specific conductivity were gathered at three sites within each reach with a calibrated YSI meter (Model 556 MPS, Yellow Spring Instruments, $\mathrm{OH})$. Three surface water samples were taken from each stream site using an acid washed dip bucket. To reduce the possibility of contamination, sampling was conducted first at the most downstream site and then proceeding upstream. Six tests of water quality were conducted using Standard Methods and EPA protocols: total phosphorus (SM $4500 \mathrm{PE}$ ), chlorophyll a, total nitrogen (SM 4500-NO3-E), total solids (EPA 160.3), and turbidity (EPA 180.1) (http:// www.standardmethods.org/).

To characterize the riparian vegetation, three $30-\mathrm{m}$ line transects were established in the riparian area parallel to the studied stream reach. A weighted string was lowered every $20 \mathrm{~cm}$ along the transect, and the name of the first plant species touched was noted for each transect point (Richardson and King 2013).

\section{Data Analysis}

Turtle abundance was defined as the total number of all turtles captured at each site. Turtle abundance was compared between stream types using modified $t$-tests: instead of directly comparing each group using a standard $t$-test, we compared each mean difference with 999 bootstraps of the data. 
Fig. 1 Locations of reference (triangles) and restored (circles) stream sites sampled in this study in the Piedmont ecoregion of the southeastern U.S. The shaded regions show urban municipal boundaries within the study area

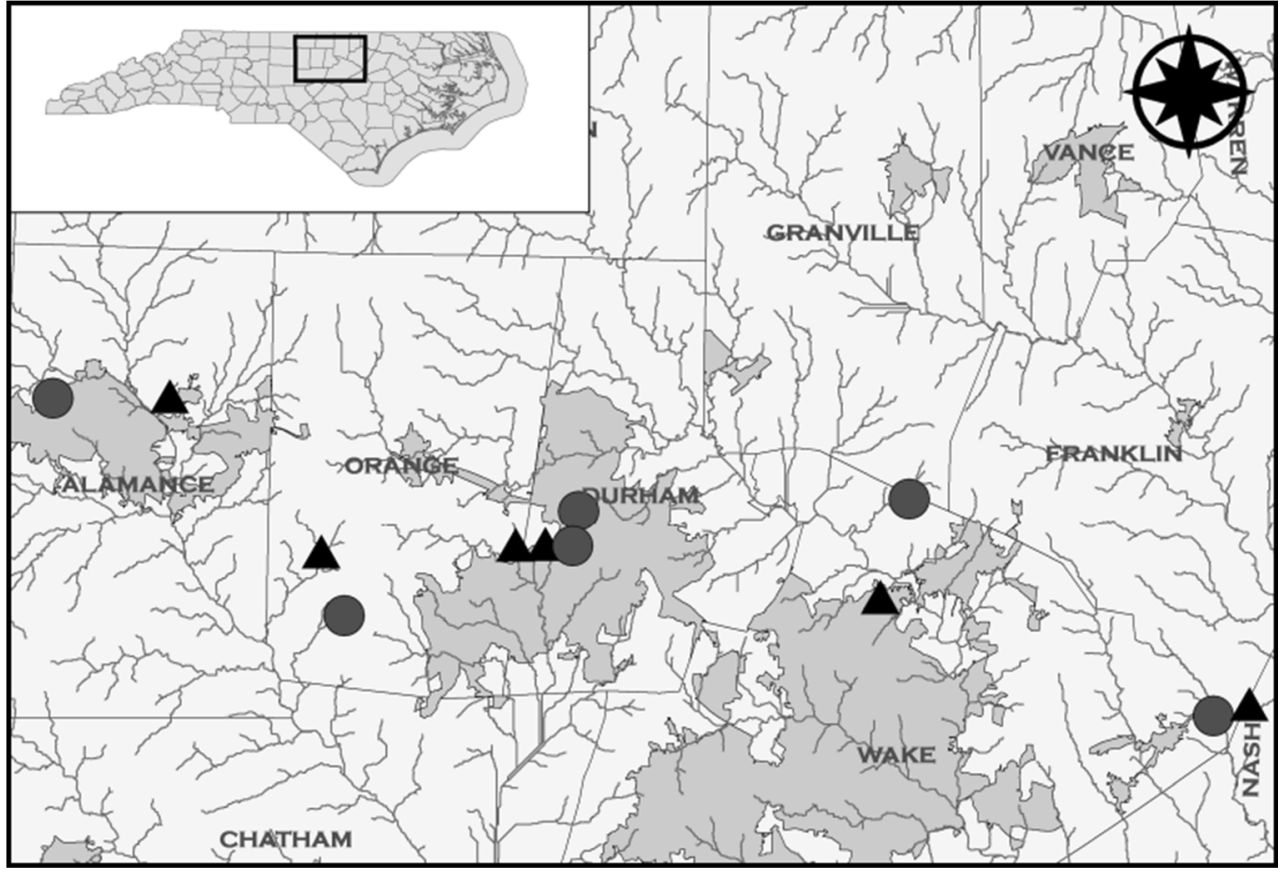

Reference and restored streams were compared for each character of interest (turtle community, habitat characteristics, and riparian plant community) using an Analysis of Similarities (ANOSIM) with the Paleontological Statistical (PAST) analytical software package (Harper et al. 2001) Similarity matrices for each of the three characters of interest were created using Chord distances. This distance metric was determined to be the most suitable for turtle and plant community data because it emphasizes differences in species proportions within each community and excludes joint absences (Anderson et al. 2011). It also provided a way to relativize the water quality and structural data. If reference and restored sites were found to be significantly different, a Similarity Analysis (SIMPER) was conducted to determine which components of the matrix contributed most to differences between site types.

Mantel's tests were used to calculate correlations between turtle species composition, and habitat and riparian plant characteristics to examine potential predictors of turtle assemblages. If the Mantel's test indicated that the correlation was significant, habitat and riparian plant matrices (developed with Chord distances) were plotted using non-metric multidimensional scaling (NMDS) techniques. Non-metric multidimensional scaling (NMDS) is a multivariate statistical method that

Table 1 Twelve stream study site codes (repeated in later tables and figures), locations, stream order, lentic habitat within $1 \mathrm{~km}$ radius, years since restoration (time restored), and restoration size

\begin{tabular}{lllllllll}
\hline & Site & Code & Latitude & Longitude & Order & Lentic Habitat $\left(\mathrm{m}^{2}\right)$ & Age (year) & Restoration Size \\
\hline Reference & Boyds Creek & BOY & $36.1203^{\circ}$ & $-79.3683^{\circ}$ & 2 & 338,844 & NA & NA \\
& Cane Creek & CAN & $35.9863^{\circ}$ & $-79.2070^{\circ}$ & 1 & 66,800 & NA & NA \\
& Cedar Creek & CED & $35.9475^{\circ}$ & $-78.6191^{\circ}$ & 2 & 150,878 & NA & NA \\
& Mud Creek & MUD & $35.9932^{\circ}$ & $-78.9713^{\circ}$ & 2 & 22,480 & NA & NA \\
& Piney Creek & PIN & $35.9922^{\circ}$ & $-79.0025^{\circ}$ & 1 & 9,967 & NA & NA \\
& Turkey Creek & TUR & $35.8539^{\circ}$ & $-78.2316^{\circ}$ & 3 & 45,866 & NA & NA \\
Restored & Bold Run Creek & BOL & $36.0322^{\circ}$ & $-78.5588^{\circ}$ & 1 & 36,727 & 2 & $496.5 \mathrm{~m}$ stream \\
& Collins Creek & COL & $35.9315^{\circ}$ & $-79.1829^{\circ}$ & 1 & 18,262 & 2 & $2881.27 \mathrm{~m} \mathrm{stream}$ \\
& Ellerbe Creek & ELL & $36.0228^{\circ}$ & $-78.9306^{\circ}$ & 2 & 57,270 & 5 & $1913.84 \mathrm{~m}$ stream \\
& Glen Raven Creek & GLE & $36.1178^{\circ}$ & $-79.4903^{\circ}$ & 2 & 40,102 & 3 & $732.13 \mathrm{~m} \mathrm{stream}$ \\
& Moccasin Creek & MOC & $35.8430^{\circ}$ & $-78.2703^{\circ}$ & 1 & 75,376 & 4 & $54.86 \mathrm{~m} \mathrm{stream,} 14,973 \mathrm{~m}^{2}$ riparian buffer \\
Sandy Creek & SAN & $35.9912^{\circ}$ & $-78.9428^{\circ}$ & 2 & 26,823 & 3 & $14568.7 \mathrm{~m}^{2}$ restoration and creation \\
\hline
\end{tabular}

More information on each restoration project can be found at portal.ncdenr.org/web/eep and clicking on the "Project Documents" link 
can be used to simplify complex species community and other ecological data by ordinating (systematically arranging) the information on a pre-determined number of axes in a way that reflects the ecological differences between samples (Kenkel and Orlóci 1986). Once data are ordinated on the axes in a way that captures the maximum amount of data variability, the data can be plotted to look for potential clustering of samples (e.g. by site type) and trends between species composition and environmental variables. NMDS offers an unbiased summary of ecological data in addition to providing a simplified technique for visualizing complex data. Once NMDS analyses were complete for habitat and riparian vegetation parameters, turtle community data were overlaid in the form of vectors to show relationships between the site characteristics and individual turtle species. Statistical significance for all statistical tests was set at an alpha value of 0.05 .

\section{Results}

\section{Turtle Community Characteristics}

A total of 77 turtles were captured representing eight Piedmont turtle species; see Supplementary Materials (S1), Palmer and Braswell (1995), and Ernst and Lovich (2009) for greater details regarding the ecology and characteristics of these species. At the reference sites, 24 turtles representing five species were captured, while 53 turtles representing seven species were captured at the restored sites (Table 2). Although abundance was not significantly different between site types $(P=0.13)$, mean turtle abundance at restored sites $(\approx 9)$ was more than twice that of reference sites $(\approx 4)$.

ANOSIM results indicate that turtle communities do not significantly differ between reference and restored sites $(P=$ 0.31 ), but within species abundance did not appear to be evenly distributed between site types. Of the eight species trapped, three were only found at restored streams (C. guttata, K. subrubrum, and T. scripta elegans), and more than double the number of $C$. picta, C. serpentina, and T. scripta scripta individuals were captured at restored streams than at reference streams. P. floridana was only captured at reference streams, and $S$. odoratus was found more frequently in reference streams.

\section{Habitat Characteristics}

Reference and restored stream sites differed significantly in terms of their habitat (structural and water quality) characteristics (ANOSIM analysis, $P=0.006$ ) (Table 3). The SIMPER analysis indicated that three water quality and one structural habitat quality contributed to the greatest difference between stream types ( $>85 \%$ of difference explained). Compared with restored streams, reference streams had lower total phosphorus (44.8 vs. $94.8 \mu \mathrm{g} / \mathrm{L}$ ), higher mean canopy cover (73.1 vs. $27.1 \%$ ), lower mean concentration of total solids (74.9 vs. $123.1 \mathrm{mg} / \mathrm{L}$ ), and lower dissolved oxygen (49 vs. $58.2 \%$ saturation)).

Riparian plant communities also differed significantly between restored and reference streams (ANOSIM analysis, $P=$ 0.002). Of the 141 plant species identified, 23 species were found at both site types, 65 were found only at restored sites, and 53 were found only at reference sites (Supplementary Materials S2). Of the 60 species included in the SIMPER analysis (those that occurred at $2+$ sites), five plant species were identified that contribute the most to differences between site types. Three species were more representative of reference sites (Microstegium vimineum, Smilax rotundifolia, and Carpinus caroliniana,). Two species were only found in restored streams and had relatively high abundance at these sites: Juncus effusus and Schedonorus arundinaceus.

\section{Turtle Community and Habitat Correlations}

The Mantel's test indicated that turtle community composition was significantly correlated with habitat parameters (water quality and structural) that separate the two stream types $(P=0.015, r=0.342)$ (Fig. 2). S. odoratus and P. floridana were more frequently associated with habitat characteristics of reference streams. S. odoratus in particular was more frequently associated with lower order reference streams. All other turtle species were more frequently associated with the habitat characteristics of restored streams. Within the restored stream group, T. scripta elegans and C. serpentina were more highly correlated with the habitat conditions of Ellerbe Creek and Sandy Creek. T. scripta scripta fell in the middle of the restoration habitat conditions, while C. guttata, K. subrubrum, and $C$. picta were more highly correlated with the remaining restored streams.

Turtle community composition was also correlated with riparian plant community data $(P=0.041, r=0.274)$. However, only two turtle species appeared to separate between riparian communities of restored streams and those of reference streams. $C$. serpentina was most highly associated with the riparian communities of restored streams, while $P$. floridana was most highly associated with the riparian community of reference streams.

\section{Discussion}

This exploratory study addresses a crucial yet largely unanswered question of how stream restoration affects turtle community composition and whether differences in turtle habitat reflect observed differences in turtle composition. Our 
Table 2 Number of turtles captured at each of the twelve stream sties for each of the following species: C. guttata (CG), C. picta (CP), C. serpentina (CS), K. subrubrum (KS), P. floridana (PF), S. odoratus (SO), T. scripta elegans (TE) and T. scripta scripta (TS)

\begin{tabular}{lcccccccccc}
\hline Site & CG & CP & CS & KS & PF & SO & TE & TS & Total \# Turtles & \# Species/ Site \\
\hline Reference sites & & & & & & & & & & \\
$\quad$ BOY & 0 & 0 & 0 & 0 & 0 & 0 & 0 & 0 & 0 & 0 \\
CAN & 0 & 1 & 1 & 0 & 0 & 3 & 0 & 1 & 6 & 4 \\
CED & 0 & 0 & 2 & 0 & 0 & 0 & 0 & 1 & 3 & 3 \\
MUD & 0 & 0 & 2 & 0 & 0 & 1 & 0 & 1 & 4 & 3 \\
PIN & 0 & 0 & 1 & 0 & 0 & 1 & 0 & 3 & 5 & 3 \\
TUR & 0 & 1 & 1 & 0 & 1 & 3 & 0 & 0 & 6 & 5 \\
Total reference & 0 & 2 & 7 & 0 & 1 & 8 & 0 & 6 & 24 & 1 \\
Restored sites & & & & & & & & & \\
BOL & 0 & 0 & 3 & 0 & 0 & 0 & 0 & 0 & 3 & 2 \\
COL & 0 & 1 & 3 & 0 & 0 & 3 & 0 & 0 & 7 & 2 \\
ELL & 0 & 0 & 6 & 0 & 0 & 0 & 0 & 2 & 8 & 5 \\
GLE & 0 & 0 & 2 & 1 & 0 & 0 & 0 & 0 & 3 & 7 \\
MOC & 2 & 5 & 0 & 4 & 0 & 2 & 0 & 9 & 22 & 5 \\
SAN & 0 & 1 & 2 & 0 & 0 & 0 & 4 & 3 & 10 & 53 \\
Total restored & 2 & 7 & 16 & 5 & 0 & 5 & 4 & 14 & 53 \\
\hline
\end{tabular}

research of turtle communities in the southeastern Piedmont documented twice the mean abundance of turtles in restored streams than reference streams. While not statistically significant, these findings suggest a trend that may have biological significance and deserves additional study. The ANOSIM analysis indicated that turtle community composition did not statistically differ between reference and restored streams, but we did observe trends in species distribution based on the life history traits of the turtles. Additionally, habitat characteristics important to turtles were significantly different between restored and reference streams, and these habitat characteristics were correlated with trends in turtle community composition that showed separation between restored and reference streams.

Our results show important differences in turtle habitat characteristics (structural and water quality) between reference and restored streams that suggest that restored streams are more suitable habitat for most aquatic and semiaquatic turtles of the Piedmont. Reference streams were more typical of forested headwater streams within the Piedmont, including higher canopy cover, lower total suspended solids, and lower primary production (lower total phosphorus and lower daytime dissolved oxygen). In contrast, restored streams were characterized by habitat and water quality features of more open water systems: lower canopy cover, higher total suspended solids, and higher primary productivity (due to higher nutrients and increased light) (Hladyz et al. 2011). Differences in canopy cover between stream types are partially a function of the process by which streams are typically restored, and partially due to the age of restored streams. Larger trees might be removed purposely, if the restoration incorporates channel reconfiguration, or incidentally to make
Table 3 Mean differences between reference and restored streams for structural and water quality characteristics, and percent contribution of variable to differences between restored and reference sites using SIMPER analysis

\begin{tabular}{lccc}
\hline Variable & Reference mean $\pm 1 \mathrm{SE}$ & Restored mean $\pm 1 \mathrm{SE}$ & Contribution \\
\hline Total Phosphorus $(\mu \mathrm{g} / \mathrm{L})$ & $44.8 \pm 7.0$ & $94.8 \pm 28.2$ & $29.1 \%$ \\
Canopy $(\%)$ & $73.1 \pm 4.4$ & $27.2 \pm 7.3$ & $24.4 \%$ \\
Total Solids $(\mathrm{mg} / \mathrm{L})$ & $74.9 \pm 9.7$ & $123.1 \pm 18.8$ & $20.3 \%$ \\
Dissolved Oxygen $(\%)$ & $49.0 \pm 10.1$ & $58.2 \pm 12.8$ & $13.2 \%$ \\
Depth $(\mathrm{cm})$ & $49.3 \pm 8.3$ & $38.0 \pm 2.7$ & $6.2 \%$ \\
Bank Slope $\left({ }^{\circ}\right)$ & $39.5 \pm 5.2$ & $22.4 \pm 6.1$ & $5.1 \%$ \\
Turbidity $(\mathrm{NTU})$ & $9.32 \pm 3.40$ & $11.13 \pm 4.91$ & $1.1 \%$ \\
Total Nitrogen $(\mu \mathrm{g} / \mathrm{L})$ & $1087 \pm 36$ & $4.37 \pm 2.33$ & $0.2 \%$ \\
Chlorophyll a $(\mu \mathrm{g} / \mathrm{L})$ & $1.73 \pm 0.51$ & $3.4 \pm 0.5$ & $0.2 \%$ \\
Baseflow Width $(\mathrm{m})$ & $5.7 \pm 0.9$ & $0.18 \pm 0.04$ & $0.1 \%$ \\
Specific Electrical Conductivity $(\mathrm{mS} / \mathrm{cm})$ & $0.14 \pm 0.03$ & & $<0.1 \%$ \\
\hline
\end{tabular}


Fig. 2 Plot of the twelve study streams based on an NMDS threeaxis analysis of the (a) habitat (structure and water quality) and (b) riparian vegetation dissimilarity matrices constructed using Chord distances. The two axes selected for display represent the two with the greatest degree of separation between reference and restored sites. The gray circles represent the restored sites and the black circles represent the reference sites. The arrows show the correlation vectors for the turtle species associated with the NMDS axes
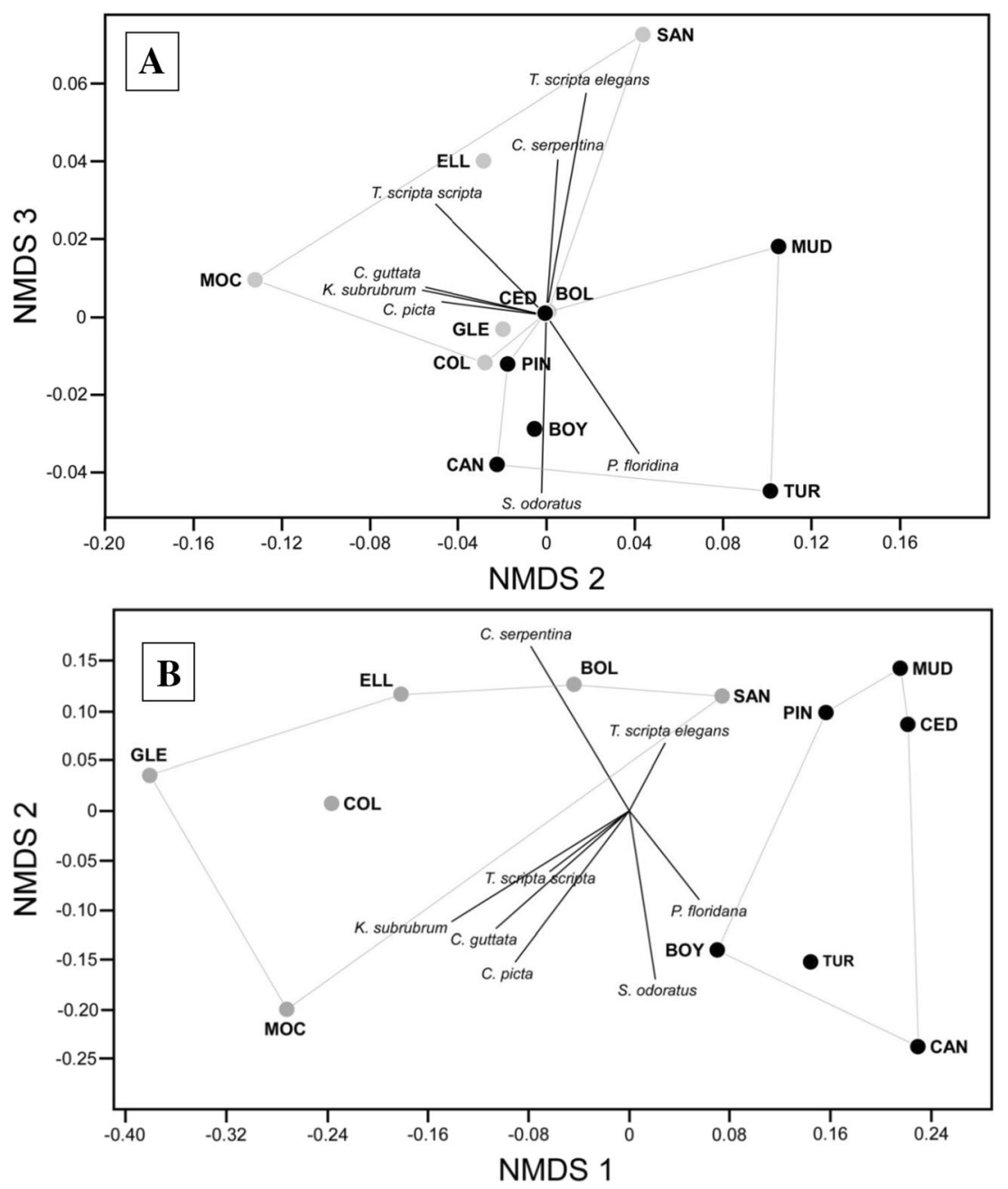

way for larger machinery. Differences in shading of streams may contribute to the disparity in turtle species composition between site types both directly and indirectly. Shading of streams directly affects turtles by reducing the number of available basking sites, an important habitat requirement of many turtle species (Bulté and Blouin-Demers 2010). In their study of urban vs. reference streams in the southeastern Piedmont, Barrett and Guyer (2008) documented an increase in the number of aquatic turtles in urban streams, which they attributed to the presence of open canopy and warmer waters. Studies of Piedmont turtles in human-altered lentic environments also suggests high light environments are of importance to turtles (Guzy et al. 2013).

Light attenuation through increased canopy cover both reduces in-stream primary productivity and alters the composition of understory vegetation. Differences in in-stream productivity between restored and reference sites may have bottom-up effects on turtle abundance (Aresco 2009). In their study on human-modified ponds, Failey et al. (2007) argue that turtles benefit from human activities that maintain or increase open-canopy habitats, and restored streams in the
Piedmont may offer important habitat for semi-aquatic turtles as natural open-canopy wetlands continue to be lost. Higher total suspended solids in restored streams indicate the presence of high sediment load and are likely responsible for the higher turbidity at these sites. It is possible that turtles prefer the more turbid water of restored streams as well; Glorioso et al. (2010) found that certain turtle species preferentially live in murky waters.

Our results also indicate that riparian plant community composition is an important habitat variable separating reference and restored streams, and restored streams have plants indicative of better turtle habitat. Two plant species characteristic of reference sites, $C$. caroliniana and $S$. rotundifolia, are native, woody understory species that are common in forested areas of the Piedmont. The dominance of these species further supports the idea that reference streams are more typical forested headwater streams. Another plant species ubiquitous in the reference sites is $M$. vimineum, a highly invasive grass species. Despite their close proximity to the stream, none of these species is an obligate or facultative wetland plant species; this may suggest that reference streams may not be 
hydrologically well-connected with their floodplain due to increased channel incision. Reference streams were also characterized by steeper slopes and deeper pools than restored streams, further suggesting some degree of stream incision at these sites. Additionally, the high mean abundance of $M$. vimineum at all of the reference streams provides further evidence of some degradation at reference sites and a lack of continued riparian flooding (DeMeester and Richter 2010; Ho and Richardson 2013). The reference sites in this study were carefully selected for maximum stream quality and minimum degradation. Evidence of channel and riparian degradation in the selected reference sites further suggests that stream degradation is unavoidable across the Piedmont area as a remnant of post-settlement, widespread farming (Walter and Merritts 2008) and rapid development across the region (Napton et al. 2010). Restored streams were characterized by a different invasive grass species, $S$. arundinaceus, which is more prevalent in high light environments more typical of this stream type. However, J. effusus was also prevalent at restored stream sites. $J$. effuses is a facultative wetland species commonly found in shallow emergent freshwater wetlands (Ervin and Wetzel 2002; USDA 2014), and likely indicates high connectivity between the stream and its floodplain. While no direct connection between turtles and any of these important plant species could be found in the literature, we speculate that the presence of $J$. effusus is indicative of the type of habitat (wetland or non-wetland) historically available to turtle species. Thus, stream channels that are highly connected with their floodplains can create the backwater areas necessary for $J$. effuses' survival as well as increasing the amount and variability of aquatic habitat available for turtle communities. Other studies also document changes in turtle composition due to reduced riparian food sources and habitat as a result of stream incision (Bodie 2001).

Differences in habitat and vegetation characteristics between sites may also explain the differences observed in the distribution of turtle species between reference and restored sites. Of the eight turtle species documented in this study, six turtle species were more prevalent or only captured at restored sites. C. guttata was only captured at the restored stream location (Moccasin Creek) that most closely met its habitat preference for higher abundance of aquatic vegetation and slower moving water (Buhlmann et al. 2008). Documentation of $C$. guttata is noteworthy, given its elusive nature and its conservation status in three southeastern states (LeGrand et al. 2008). K. subrubrum (a widespread Piedmont species) was captured exclusively at two restored sites, possibly reflecting its preference for the dense riparian ground vegetation more prevalent in open canopy conditions (Buhlmann et al. 2008). T. scripta elegans was only captured at one highly urban stream restoration site. This sub-species of T. scripta is a particularly invasive turtle species in some parts of the U.S. and in most of Europe, with the Invasive Species Specialist Group naming it in the top 100 invasive species in the world (Cadi and Joly 2004; Somma et al. 2014). T. scripta elegans is frequently found outside of its native range because individuals are often released as unwanted pets, possibly explaining its occurrence in the most urban restored stream.

The three species captured at both types of streams (but more commonly in restored sites), C. picta, C. serpentina, and T. scripta scripta, are widespread and common habitat generalists in the southeastern Piedmont (Buhlmann et al. 2008; Ernst and Lovich 2009; Graham et al. 2010). The literature suggests that these species may also be better adapted to human-modified aquatic environments, characterized by restored streams. Eskew et al. (2010b) found that survivorship and recruitment of T. scripta scripta was unaffected by development surrounding a Piedmont pond, and C. serpentina survival rates in developed ponds exceeded those of natural habitats. A study by Failey et al. (2007) found that these same three species, and to a lesser extent K. subrubrum, were common in farm and golf course ponds highly impacted by human disturbance. Interestingly, this same study found that $P$. concinna and $S$. odoratus were not as common in these highly modified habitats (see below).

The two remaining species were either captured only or more frequently at reference sites. P. floridana was captured only once in a reference stream at the eastern border of the Piedmont, which may be attributed more to the stream's proximity to the Coastal Plain ecoregion and the order of the stream (third), and less to the type of site. Only S. odoratus was captured more frequently at reference sites. S. odoratus does not readily move between aquatic habitats, and therefore may not have had enough time or reason to recolonize restored stream locations (Ernst and Lovich 2009).

Two additional site characteristics were beyond the scope of this study, but may influence turtle abundance and composition in restored and reference streams. First, the quality and size of the surrounding habitat with respect to its suitability for turtles was not examined. These characteristics can significantly affect the successful habitation and reproduction of many freshwater turtle species (Bodie and Semlitsch 2000; Attum et al. 2008; Guzy et al. 2013). Currently, the US Army Corps of Engineers and US Environmental Protection Agency compensatory mitigation requirements do not necessarily require the permitee to conserve or protect associated terrestrial components (USOFR 2008) whose size is of significance to turtles (Joyal et al. 2001). If restoration efforts do not consider the importance of preserving or restoring terrestrial habitat surrounding the streams, most of the nesting and hibernation sites for turtles will be outside of the restored wetland boundary (Harden et al. 2009) and may have significant implications for successful use of restored stream sites by turtles to maintain their populations. Thus, surrounding suitable nesting habitat and reduction of proximity to roads may be 
particularly important when restoration projects are conducted in residential areas (Price et al. 2013).

The second factor not considered in this study was the degree of connectivity of the restored streams with other locations that might affect turtle distribution and re-colonization, and which has been found to affect rare species of reptiles. Bodie and Semlitsch (2000) documented turtle colonization in newly formed wetlands within 5 years of their creation, and Bowers et al. (2000) found low level recolonization of most species of reptiles and amphibians in a stream system in South Carolina, 2 to 3 years after hot water from a nuclear facility devastated local flora and fauna. Thus colonization of restored streams within 2 to 4 years postrestoration is not unexpected, especially given the high number of open water habitats within one $\mathrm{km}$ radius of each stream (Table 1) that could serve as potential source populations.

This study only considered adult turtle captures at each of the stream sites, but did not quantify signs of turtle reproduction or the presence of other life stages. A study by Eskew et al. (2010a) suggested that there may be a substantial lag time between habitat modification and the effect on adult turtle populations for C. picta, and Eskew et al. (2010b) indicated that $C$. serpentina had low recruitment in developing sites. We suggest that collection of age distribution data will be necessary to more thoroughly assess whether turtle populations are sustainable in both reference and restored stream systems.

\section{Conclusion and Implications}

This study takes a first step towards determining if restored stream ecosystems can support the native freshwater turtle populations that are critical components of these systems in the southeastern Piedmont. Given their integral role in stream ecosystems, turtles are uniquely situated to offer understanding of the success of restoration efforts. Our findings have two important implications regarding stream restoration in the Piedmont and consequently, for the conservation of native turtle species in the region. First, the habitat analyses indicate that the reference streams examined in this study were more characteristic of typical shaded forest headwater streams in the Piedmont, with some evidence that channel incision and degradation from the abundance of invasive riparian plants may be widespread in this region, thus providing less turtle habitat. In contrast, restored sites' characteristics were more similar to high light, open water habitats, more highly connected with their floodplain, which have been found to be preferable to many turtle species in studies of lentic habitats in this region (Guzy et al. 2013). Second, our study suggests that there is a trend towards higher turtle abundance, and possibly different turtle communities, at restored streams due to differences in habitat characteristics. Monitoring turtle species populations at restoration sites in the future is critical for the conservation of these organisms in an increasingly managed network of freshwater systems (Bodie 2001; Hobbs and Cramer 2008). As habitat loss and degradation continue to contribute to turtle population declines worldwide and the number of restored streams increases on the landscape (Meyers and Pike 2006; Barrett and Guyer 2008), ecologically sound restored habitats may serve as critical habitat resources for long-term turtle conservation.

Acknowledgments The authors thank Mary Patricia Nowalk, Dean Urban, Wes Willis, Jean Still, Joshua Unghire, and Christopher Dudley. Funding provided by the Duke Wetland Center Endowment and the NC Clean Water Management Trust Fund.

\section{References}

Abramoff MD, Magelhaes PJ, Ram SJ (2004) Image processing with ImageJ. Biophotonics International 11:36-42

Anderson MJ, Crist TO, Chase JM, Vellend M, Inouye BD, Freestone AL, Sanders NJ, Cornell HV, Comita LS, Davies KF, Harrison SP, Kraft NJB, Stegen JC, Swenson NG (2011) Navigating the multiple meanings of $\beta$ diversity: a roadmap for the practicing ecologist. Ecology Letters 14:19-28

Aresco MJ (2009) Environmental correlates of the abundances of three species of freshwater turtles in lakes of northern Florida. Copeia 2009:545-555

Attum O, Lee YM, Roe JH, Kingsbury BA (2008) Wetland complexes and upland-wetland linkages: landscape effects on the distribution of rare and common wetland reptiles. Journal of Zoology 275:245-251

Barrett K, Guyer C (2008) Differential responses of amphibians and reptiles in riparian and stream habitats to land use disturbances in western Georgia, USA. Biological Conservation 141:2290-2300

Bash JS, Ryan CM (2002) Stream restoration and enhancement projects: is anyone monitoring? Environmental Management 29:877-885

Bodie JR (2001) Stream and riparian management for freshwater turtles. Journal of Environmental Management 62:443-455

Bodie JR, Semlitsch RD (2000) Spatial and temporal use of floodplain habitats by lentic and lotic species of aquatic turtles. Oecologia 122: 138-146

Bodie JR, Semlitsch RD, Renken RB (2000) Diversity and structure of turtle assemblages: associations with wetland characters across a floodplain landscape. Ecography 23:44-456

Bowers CF, Hanlin HG, Guynn DC, McLendon JP, Davis JR (2000) Herpetofaunal and vegetational characterization of a thermallyimpacted stream at the beginning of restoration. Ecological Engineering 15:S101-S114

Brown T, Derting TL, Fairbanks K (2008) The effects of stream channelization and restoration on mammal species and habitat in riparian corridors. Journal of the Kentucky Academy of Sciences 69:37-49

Buhlmann K, Tuberville T, Gibbons W (2008) Turtles of the southeast. University of Georgia Press, Athens

Bulté G, Blouin-Demers G (2010) Estimating the energetic significance of basking behaviour in a temperate-zone turtle. Ecoscience 17:387393

Cadi A, Joly P (2004) Impact of the introduction of the red-eared slider (Trachemys scripta elegans) on survival rates of the European pond turtle (Emys orbicularis). Biodiversity and Conservation 13:25112518 
Cheung SM, Dudgeon D (2006) Quantifying the Asian turtle crisis: market surveys in southern China, 2000-2003. Aquatic Conservation: Marine and Freshwater Ecosystems 16:751-770

Conant R, Collins JT (1998) A field guide to reptiles and amphibians: eastern and central North America, 3rd edn. Houghton Mifflin Company, Boston

Conner CA, Douthit BA, Ryan AJ (2005) Descriptive ecology of a turtle assemblage in an urban landscape. American Midland Naturalist 153:428-435

Conover D, Klein J (2010) Changes in a restored wetland during 18 years of management (Ohio). Ecological Restoration 28:248-250

Convertino M, Baker KM, Vogel JT, Lu C, Suedel B, Linkov I (2013) Multi-criteria decision analysis to select metrics for design and monitoring of sustainable ecosystem restorations. Ecological Indicators 26:76-86

DeMeester DE, Richter DB (2010) Restoring restoration: removal of the invasive plant Microstegium vimineum from a North Carolina wetland. Biological Invasions 12:781-793

Doll BA, Grabow GL, Hall KR, Halley J, Harman WA, Jennings GD, Wise DE (2003) Stream restoration: a natural channel design handbook. NC Stream Restoration Institute, NC State University. $128 \mathrm{pp}$

DonnerWright DM, Bozek MA, Probst JR, Anderson EM (1999) Responses of turtle assemblage to environmental gradients in the St. Croix River in Minnesota and Wisconsin, USA. Canadian Journal of Zoology 77:989-1000

Ernst CH (1971) Population dynamics and activity cycles of Chrysemys picta in southeastern Pennsylvania. Journal of Herpetology 5:151160

Ernst CH, Lovich JE (2009) Turtles of the United States and Canada. Johns Hopkins University, Baltimore

Ernst AG, Warren DR, Baldigo BP (2012) Natural-channel-design restorations that changed geomorphology have little effect on macroinvertebrate communities in headwater streams. Restoration Ecology 20:532-540

Ervin GN, Wetzel RG (2002) Influence of a dominant macrophyte, Juncus effusus on wetland plant species richness, diversity and community composition. Oecologia 130:626-636

Eskew EA, Price SJ, Dorcas ME (2010a) Survivorship and population densities of painted turtles (Chrysemys picta) in recently modified suburban landscapes. Chelonian Conservation and Biology 9:244 249

Eskew EA, Price SJ, Dorcas ME (2010b) Survival and recruitment of semi-aquatic turtles in an urbanized region. Urban Ecosystems 13: 365-374

Failey EL, McCoy JC, Price SJ, Dorcas ME (2007) Ecology of turtles inhabiting golf course and farm ponds in the western Piedmont of North Carolina. Journal of the North Carolina Academy of Science 123:221-232

Gage MS, Spivak A, Paradise CJ (2004) Effects of land use and disturbance on benthic insects in headwater streams draining small watersheds north of Charlotte, NC. Southeastern Naturalist 3:345-358

Gibbs JP, Steen DA (2005) Trends in sex ratios of turtles in the United States: implications of road mortality. Conservation Biology 19: $552-556$

Glorioso BM, Vaughn AJ, Waddle JH (2010) The aquatic turtle assemblage inhabiting a highly altered landscape in southeast Missouri. Journal of Fish and Wildlife Management 1:161-168

Graham SP, Steen DA, Nelson KT, Durso AM, Maerz JC (2010) An overlooked hotspot? Rapid biodiversity assessment reveals a region of exceptional herpetofaunal richness in the southeastern United States. Southeastern Naturalist 9:19-34

Groffman PM, Bain DJ, Band LE, Belt KT, Brush GS, Grove JM, Pouyat RV, Yesilonis IC, Zipperer WC (2003) Down by the riverside: urban riparian ecology. Frontiers in Ecology and the Environment 1:315321
Guzy JC, Price SJ, Dorcas ME (2013) The spatial configuration of greenspace affects semi-aquatic turtle occupancy and species richness in a suburban landscape. Landscape and Urban Planning 117: 46-56

Harden LA, Price SJ, Dorcas ME (2009) Terrestrial activity and habitat selection of eastern mud turtles (Kinosternon subrubrum) in a fragmented landscape: implications for habitat management of golf courses and other suburban environments. Copeia 2009:78-84

Harper Ø, Harper DAT, Ryan PD (2001) PAST: paleontological statistics software package for education and data analysis. Palaeontologia Electronica 4(art. 4):9

Heinrich KK, Whiles MR, Roy C (2014) Cascading ecological responses to an in-stream restoration project in a midwestern river. Restoration Ecology 22:72-80

Hladyz S, Åbjörnsson K, Giller PS, Woodward G (2011) Impacts of an aggressive riparian invader on community structure and ecosystem functioning in stream food webs. Journal of Applied Ecology 48: 443-452

Ho M, Richardson CJ (2013) A five year study of floristic succession in a restored urban wetland. Ecological Engineering 61:511-518

Hobbs RJ, Cramer VA (2008) Interventionist approaches for restoring and maintaining ecosystem function in the face of rapid environmental change. The Annual Review of Environment and Resources 33:39-61

Horwitz RJ, Johnson TE, Overbeck PF, O’Donnel TK, Hession WC, Sweeney BW (2008) Effects of riparian vegetation and watershed urbanization on fishes in streams of the mid-Atlantic Piedmont (USA). Journal of the American Water Resources Association 44: 724-741

Iverson JB (1982) Biomass in turtle populations: a neglected subject. Oecologia 55:69-76

Jähnig SC, Lorenz AW, Hering D, Antons C, Sundermann A, Jedicke E, Haase P (2011) River restoration success: a question of perception. Ecological Applications 21:2007-2015

Joyal LA, McCollough M, Hunter ML (2001) Landscape ecology approaches to wetland species conservation: a case study of two turtle species in southern Maine. Conservation Biology 15:1755-1762

Kenkel NC, Orlóci L (1986) Applying metric and nonmetric multidimensional scaling to ecological studies: some new results. Ecology 67 : 919-928

LeGrand HE, McRae SE, Hall SP, Finnegan JT (2008) Natural heritage program list of the rare animal species of North Carolina. North Carolina Natural Heritage Program, NC Department of Environment and Natural Resources

Lewis GP, Mitchell JD, Andersen CB, Haney DC, Liao M, Sargent KA (2007) Urban influences on stream chemistry and biology in the Big Brushy Creek Watershed, South Carolina. Water, Air, and Soil Pollution 182:303-323

Meyers JM, Pike DA (2006) Herpetofaunal diversity of Alligator river national wildlife refuge, North Carolina. Southeastern Naturalist 5: 235-252

Napton DE, Auch RF, Headley R, Taylor JL (2010) Land changes and their driving forces in the southeastern United States. Regional Environmental Change 10:37-53

North Carolina Division of Water Quality (2008) North Carolina Integrated Report Categories 4 and 5 (Impaired Waters List). Available via http://portal.ncdenr.org/c/document library/get file? uuid=9f453bf9-2053-4329-b943-6614bd4e709a\&groupId=38364

Palmer WM, Braswell AL (1995) Reptiles of North Carolina. University of North Carolina Press, Chapel Hill

Palmer MA, Menninger HL, Bernhardt E (2009) River restoration, habitat heterogeneity and biodiversity: a failure of theory or practice? Freshwater Biology 55(Suppl 1):1-18

Pearse DE, Arndt AD, Valenzuela N, Miller BA, Cantarelli V, Sites JW (2006) Estimating population structure under non-equilibrium conditions in a conservation context: continent-wide population 
genetics of the giant Amazon River turtle, Podocnemis expansa (Chelonia; Podocnemididae). Molecular Ecology 15:985-1006

Price SJ, Guzy J, Witczak L, Dorcas ME (2013) Do ponds on golf courses provide suitable habitat for wetland-dependent animals in suburban areas? An assessment of turtle abundances. Journal of Herpetology 47:243-250

Raborn SW, Schramm H (2003) Fish assemblage response to recent mitigation of a channelized warmwater stream. River Research and Applications 19:289-301

Richardson JS (2004) Meeting the conflicting objectives of stream conservation and land use through riparian management: another balancing act. In: Scrimgeour GJ, Eisler G, McCulloch B, Silins U, Monita M (eds) Forest-Land-Fish Conference II - Ecosystem stewardship through collaboration. Proc. Forest-Land-Fish Conf. II, April 26-28, 2004, Edmonton, Alberta, pp. 1-6

Richardson CJ, King RS (2013) A primer on sampling plant communities in wetlands. In: DeLaune RD, Reddy KR, Richardson CJ, Megonigal JP (eds) Methods in biogeochemistry of wetlands. Soil Science Society of America, Inc, Madison, pp 197-224

Richardson CJ, Flanagan N, Ho M, Pahl J (2011) Integrated stream and wetland restoration: a watershed approach to improved water quality on the landscape. Ecological Engineering 37:25-39

Schnoonover JE, Lockaby BG (2006) Land cover impacts on stream nutrients and fecal coliform in the lower Piedmont of West Georgia. Journal of Hydrology 331:371-382

Seavy NE (2012) Developing a riparian bird index to communicate restoration success in Marin County, California. Ecological Restoration 30:157-160

Semlitsch RD, Bodie JR (2003) Biological criteria for buffer zones around wetlands and riparian habitats for amphibians and reptiles. Conservation Biology 17:1219-1228
Somma LA, Foster A, Fuller P (2014) Trachemys scripta elegans. USGS nonindigenous aquatic species database, Gainesville, FL. Available via http://nas.er.usgs.gov/queries/FactSheet.aspx?speciesID=1261. Accessed on 26 Sept 2014

Steen DA, Gibbs JP (2004) Effects of roads on the structure of freshwater turtle populations. Conservation Biology 18:1143-1148

Sudduth EB, Hassett BA, Cada P, Bernhardt ES (2011) Testing the field of dreams hypothesis: functional responses to urbanization and restoration in stream ecosystems. Ecological Applications 21: 1972-1988

Tran SL, Moorhead DL, McKenna KC (2007) Habitat selection by native turtles in a Lake Erie Wetland, USA. American Midland Naturalist 158:16-28

US Army Corps of Engineers (2008) Regulatory guidance letter: No. 0803

US Department of Agriculture (2014) Plants Database. Available via http://plants.usda.gov/. Accessed on 26 Sept 2014

US Office of the Federal Register (2008) Compensatory mitigation for losses of aquatic resources. Code of the Federal Regulations, Title 40, Part 230. U.S. Government Printing Office, Washington, D.C.

Walter RC, Merritts DJ (2008) Natural streams and the legacy of waterpowered mills. Science 319:299-304

Wilson J, Kornilev Y, Anderson W, Connette G, Eskew E (2014a) Yellowbelly slider: Trachemys scripta. Davidson College. Available via http://www.bio.davidson.edu/projects/herpcons/ herps_of_NC/turtles/Trascr/trascr.html. Accessed on 26 Sept 2014

Wilson J, Kornilev Y, Anderson W, Connette G, Eskew E (2014b) Eastern mud turtle: Kinosternon subrubrum. Davidson College. Available via http://www.bio.davidson.edu/projects/herpcons/ herps_of_NC/turtles/Kinsub/kinsub.html. Accessed on 26 Sept 2014 